\title{
Türk Sanat ve Halk Müziği Çalgılarıyla Yürütülen Müzik Dersi Uygulamalarının İlköğretim Öğrencilerinin Ders Başarı ve Tutumlarına Etkisi
}

\section{Serpil UMUZDAŞ*, Hamza Oruç KIZIKLI**, M. Serkan UMUZDAŞ****}

Öz: Bu çalışmada, Türk Sanat ve Halk müziği çalgılarıyla yürütülen müzik dersi uygulamalarının ilköğretim öğrencilerinin ders başarı ve tutumlarına etkisini belirlemek amaçlanmıştır. Bu çalışmada, seçkisiz atanan bir kontrol ve iki deney grubuna öntest -sontest ölçümleri yapılarak; kanun ve bağlama çalgılarıyla yapılan müzik dersi uygulamalarının, ilköğretim öğrencilerinin müzik ders başarısı ve tutumlarına etkileri sınanmıştır. Araştırma, aynı sayıda öğrenciden oluşan üç farklı sınıfta uygulanmıştır. Sınıflardan ikisi deney, biri ise

kontrol grubu olarak oluşturulmuştur. Güz döneminde deney guruplarını oluşturan iki şubeden rastgele birine kanun diğer şubeye ise bağlama çalgısı kullandırılarak müzik dersi yürütülmüştür. Kontrol grubuna ise çalgı kullanılmadan deney gruplarıyla aynı içeriğe sahip

öğretim süreci işlenmiştir. Başarı testi olarak; "Kızıklı 6. sınıf müzik dersi başarı testi”, öğrencilerin tutumlarının belirlenmesin de ise "Umuzdaş ilköğretim müzik dersi tutum ölçeği

(2012)" kullanılmıştır. İlköğretim müzik dersi öğrencilerinin tutum ve başarılarına yönelik araştırmalar incelendiğinde; müzik eğitiminde kullanılan çalgıların, müzik dersinin işlenişi açısından önemli bir yeri olduğu görülmektedir. Araştırmalardan elde edilen sonuçlar incelendiğinde, ilköğretim düzeyi müzik derslerinde çalg1 eşliği kullanılarak işlenen müzik derslerinin, öğrencilerin başarısı ve derse yönelik ilgilerine olumlu etki ettiğini gözlenmektedir. Ancak bu çalışmadaki deneyde kullanılan çalgılar ve çalgısız eğitim yapılan kontrol grubuna ait ortalama değerler ve çalışmada incelenen değişkenlere ilişkin ortalama değerler farklı olsa da, bunlar istatistiki bakımdan anlamlı değildir. Deney için seçilen çalgılar, araştırmada kullanılan değişkenlere etki etmemiştir.

Anahtar Kelimeler: İlköğretim Müzik Dersi, Türk Müziği Çalgıları, Bağlama, Kanun, Başarı, Tutum.

\footnotetext{
* Doç. Dr., Tokat Gaziosmanpaşa Üniversitesi, Devlet Konservatuvarı, Email: sumuzdas@hotmail.com.com Orcid No: 0000-0002-6013-2406

${ }^{* *}$ Müzik Öğretmeni, Email: hamzaoruckizikli@hotmail.com Orcid No: 0000-0002-0619-2256.

***Doç. Dr., Tokat Gaziosmanpaşa Üniversitesi, Devlet Konservatuvarı, Email: sumuzdas@yahoo.com Orcid No: 0000-0002-5455-2770
} 


\title{
The Effect of The Use of Turkish Classical and Folk Music Instruments in Music Courses on The Course Achievement and Attitude of Students in Primary School
}

\begin{abstract}
In this study, it is aimed to determine the effect of music course practices with Turkish Classical and Folk Music instruments on course achievement and attitudes of primary school students. In this study, one randomly assigned control and two experimental groups were subjected to pre-test and post-test measurements; the effects of music classes with qanun and baglama on music course achievement and attitudes of primary school students were tested. The study was conducted in three different classes consisting of the same number of students. Two of the classes were experimental and one was the control group. In the fall semester, music classes were made by using the qanun in one of the two classes that were the experimental groups and the baglama to the other class. The control group was instructed to use the same content as the experimental groups without using instruments. "K1zıkl1 6th grade music course achievement test" for achievement test, and "Umuzdaş primary school music course attitude scale (2012)” in determing the attitudes of students were used. When the researches about the attitudes and achievements of primary school music students were examined; it is seen that the instruments used in music education have an important place in terms of music courses' performance. When the results obtained from the researches are examined, it shows that the music lessons used in the primary school music classes have a positive effect on the students' achievements and interests in the course. However, although the mean values of the instruments used in the experiment and the control group with no instrument training in this study and the mean values of the studied variables were different, they were not statistically significant. The instruments chosen for the experiment did not affect the selected variables.
\end{abstract}

Keywords: Primary School Music Course, Turkish Music Instruments, Baglama, Qanun, Achievement, Attitude

\section{Giriş}


Müziğin; bireyin ve toplumun özelliklerini bünyesinde barındıran, kişiler ve gruplar arasında iletişim kurulmasını sağlayan bir rolü olduğu düşünülebilir. Müzik, toplumun tüm kesimleri içindir. Müzik eğitimi; toplumsal amaçları, duygu, düşünce ve davranış birliğinin temellerini oluşturup, değerlerin korunması geliştirilmesine katkıda bulunabilir. Nitelikli müzik eğitimi, bireyin, kendisi ile yaşam arasındaki bağı kurarak; amacını, yetenek ve becerilerini farkına varmasını, kişiliğini ve toplumları tanıması, estetik, sanatsal ve kültürel bakış açısı kazanmasını sağlayabilir.

Müzik yapmak, kendi içinde ve çevre ile uyumu gerektirdiği söylenebilir. Tek başına ya da toplu yapılan çalgı eşliği esnasında bireyin, ritimsel yönden uyumlu olması, nefes kontrolünü sağlaması, çalınan esere odaklanması, sesini kontrol etmesi ve çalınan eşlik çalgısına yoğunlaşması gerekir. Bu uyum ve odaklanma becerisi, süreç içerisinde bireyin bir özelliği haline gelir. Müzik eğitimi böylece gelişim sürecine katkı sağlayabilir. İlköğretimde de müzik derslerinin amacı bu temele dayandığı düşünülmektedir. Öğrencinin müziği ve kendi sesini sevmesi, sesini kullanması, koruması ve müzik bilincinin oluşturulması yer almaktadir.

Bir müzik eğitimcisinin müzik derslerinde kullanabileceği en işlevsel materyal, çalgısıdır. Öğrencilerin müzik dersine ilgi ve motivasyonlarının, derste kullanılan çalgılar yoluyla artabileceği düşünülmektedir. Dolayısıyla kazanımların öğretiminde kullanılan çalgılar ile pekişmesi sağlanabilir.

Eğitim fakültelerinin müzik eğitimi anabilim dallarında öğrenim gören müzik öğretmeni adayları, dört yıllık lisans eğitimleri süresince birden fazla çalgıya ilişkin eğitim almaktadır. Zorunlu olarak her öğrencinin aldığı “piyano” eğitimlerinin, öğretmenlerin mentorluğunda kendi seçtiği "bireysel çalgı" ve "okul çalgıları" eğitimleri bunlardandır. O Brien'e göre; bir resim öğretmeninin resim dersinde resim yaptırması ne kadar doğal ise bir müzik öğretmenin müzik dersinde, sesini ve çalgısını kullanması, müzik etkinlikleri ve yaratma becerileri ile dersini yürütmesi doğaldır (Akt. Göğüş, 2008). Çalgı eğitiminin birçok öğrenciye katkısından söz eden Kocabaş, çocuğun eğitimini aldığı çalgı sayesinde sesleri ve tartımları, yaşantısı yoluyla tanıdığını, ayırt ettiğini, doğru ve yanlış sesi bulabildiğini ifade etmiştir (Kocabaş, 1995). Bu bağlamda, müzik dersi kazanımlarına ulaşmada, etkinliklerin planlanmasında, çalgı kullanımı ve kullanılacak çalgıların seçiminin önemli olduğu düşünülmektedir.

İlköğretim müzik derslerinde genellikle blok flüt kullanıldığı görülmektedir (Acar ve Aydoğan, 2012). Son yıllarda yapılan çalışmalarda gitar, bağlama, melodika, mandolin gibi 
çalgıların müzik derslerinde kullanıldığı anlaşılmıştır (Altıntaş, 2007; Işık, 2008; Uluocak, 2008; Yılmaz, 2010). İlköğretim müzik derslerinde kullanılacak çalgıların, öğrencilerin eşlik edebileceği, öğrencilerin her yaşta değişebilen ses sınırlarına uygun, belli ritmik ve ezgisel özelliklere sahip olan çalgılardan seçilmesi yerinde olur.

Müzik eğitimi veren kurumlarda yetişen müzik öğretmeni adaylarına verilen piyano eğitimi, birçok okulun fiziki imkânları sebebiyle eşlik çalgısı olarak kullanılma durumlarını sınırlandırmaktadır. Bağlama, blok flüt, gitar gibi çalgıların piyanoya göre temin edilebilirliğin daha yüksek ihtimal oluşu, yer, mekân, maliyet, akort yönlerinde üstünlüklerine göre daha fazla tercih edilmektedir. Oysaki piyano müzik öğretmenlerinin en temel eşlik çalgılarındandır. Verilen eğitimler, var olan kaynaklar, metotlar, ses sınırları ve öğrencilere uygunluğu bakımından işlevselliği bu çalgıyı temel eşlik çalgısı haline dönüştürmüştür. $\mathrm{Bu}$ gibi sebepler ile alternatif olarak sistemde var olan bağlama ve sistemde daha sınırlı olan, işlevsel özellikleri bakımından piyanoya benzeyen, geleneksel çalgılardan kanun, bu çalışmada ele alınmıştır.

Genel müzik eğitimde kullanılan ezgilerin, geleneksel Türk müziğinden örnekler olması ile bilinenden bilinmeye, yakından uzağa ilkesini destekleyerek nispeten daha etkili olacağı düşünülmektedir. Dünya üzerindeki ülkeler incelendiğinde öz müziğini kaynak olarak kabul eden, planlı ve sistemli bir şekilde eğitim sistemine uygulayan, kendi içerisinde özümseyip dünya değerleri ve müzikleriyle eşdeğer kabul eden ülkeler, evrenselliği yakalayan müziğinden hiçbir şey kaybetmeyen aksine kendi müziğini dünya ülkelerine tanıtılmasını sağlamıştır.

Her ülkenin eğitim sistemi, eğitim müziği dağarında kendi kültürüne özgü müzikleri tanıtıcı içerik üretir. Türk sanat müziği ve Türk halk müziği, Türk müziğinin birer koludur. $\mathrm{Bu}$ müzik türlerinin kendi içerisinde benzerlikleri ve farklılıkları olmakla beraber aynı toplumun ürünüdür. Coğrafyanın özelliklerinden beslenen ve etkilenen her iki müzik türü, toplumun müziğini oluşturmuşstur.

Geleneksel müzikler; hayatın her alanında olması, geleneklerle yaşatılması, kulaktan kulağa varlığını sürdürmesi, ortaya çıktığı yörenin en yalın haliyle çalınış ve söyleniş özelliklerini içerisinde barındırması özelliklerini taşır. Her yörenin doğal yaşam biçiminin müziğe yansımasıyla çeşitlilik artmıştır. Süreç içerisinde ağızdan ağıza yayılarak aktarılan bu zenginlikler halkın malı haline gelmiştir. $\mathrm{Bu}$ zenginlik ise çeşitli müzikal terimlerin doğmasına sebep olmuştur. Türk halkının yaşam biçimiyle, kültürüyle, tarihiyle, coğrafi özellikleriyle, sosyo-ekonomik durumuyla sade ve en çarpıcı gerçekliğiyle bestelenen türküler 
ve şarkılar özümüzü yansıtır. Bu nedenle Türk müzik eğitiminde kullanılan ilköğretim müzik müfredatına; Türk müziğinde yer alan türküler, kaynağını Türk müziğinden alan ezgilere, Türk müziğiyle ilgili yeni konular eklenmiştir. Bu konuların Türk müziği çalgılarıyla işlenmesi yerinde olur.

Türkiye'de Türk müziği çalgılarından en yaygın kullanılan çalgının bağlama olduğu görülmektedir. Hemen hemen her yörede benimsenmesi, bu çalgıyı öne çıkarmıştır. Genel müzik eğitimde bağlama kullanımı; genellikle yılsonu konserleri, belirli gün ve haftaların etkinliklerinde, Türk halk müziği korolarında öne çıktığı görülmektedir. İlköğretim müzik derslerinde, öğrencinin çalgı çalmada aktif olduğu zamanlar sınırlıdır. Bu durum ilköğretim düzeyindeki etkinliklerde, öğrencilerin değil müzik öğretmenlerinin aktif olarak yer almasına neden olmaktadır. Müzik eğitimin sorunlarını ele alan ve bağlamanın müzik dersinde kullanımın öneminden bahseden Emnalar; ilköğretim ve ortaöğretim müzik eğitiminde, Türk halk müziğinin yer alması düşüncesinin yıllarca tartışıldığını ancak uygulamaya dönük olarak gerçekleştirilemeyen bir konu olduğunu belirtmiştir (Emnalar, 1993). Bağlama birçok evde bulunan geleneksel bir halk çalgısıdır. Teminindeki ekonomiklik, her yörede kullanılan bir çalgı olmasına kolaylık sunmaktadır. Eğitimde tüm derslerin merkezinde bulunan yakından uzağa, bilinenden bilinmeyene ilkeleri ile doğrudan örtüşmekte, yaygınlık alanı ve teminindeki kolaylık gibi birçok konuda avantajının olması nedeniyle ve bu ilkeler ile paralellik göstermektedir. İlköğretim müzik eğitiminde kullanılan müzik eserleri düşünüldüğünde, bağlamanın ses sınırları ile ilköğretim müfredatındaki kullanılan eserlerin ses sınırları arasında bağlamanın son derece uyumlu olduğu söylenebilir. Solo ve eşlik çalgısı olarak kullanılan bağlamanın, geleneksel müzikleri seslendirebilmenin yanında çağdaş müzikleri seslendirmedeki yeterliliği öne çıkmaktır. Genel müzik eğitiminde, bağlamanın ilköğretim müzik dersi hedeflerine ulaşmada yeterli ve geçerli yapısının olduğu söylenebilir. $\mathrm{Bu}$ çalgının müzik derslerinde kullanımı ise, doğru ve başarılı bir yaklaşım olarak düşünülmektedir.

Türk kültürünün ve Türk müziğinin önemli sazlarından biri olan kanun ise, sadece Türkiye değil birçok ülkede kullanılan bir mızraplı çalgıdır. Özellikle Ortadoğu ülkeleri ve Yunanistan'da kullanılan çok telli bir çalgıdır.

Sesi, tınısı ve insanda uyandırdığı etkisiyle öne çıkan kanunun, Türk müziğini seslendirmedeki başarısının yanı sıra birçok müzik türünü de seslendirebilmedeki yeteneği oldukça fazladır. Kanun, arp ve gitar tekniğiyle yakın bir teknikle parmakla çalınması ve içerisinde çok sesliliği barındırması bakımından Türk müziğinin piyanosu olarak 
isimlendirilebilir (Kahyaoğlu, 2011). Üç buçuk oktavlık ses aralığı, Tampere sisteme uygunluğu, özgün biçimi ve geçmişi tarihin köklerine dayanmasıyla öne çıkan işlevsel bir çalgıdır.

Geleneksel müzik kültürümüzün gelecek nesillere doğru ve eksiksiz aktarımında müzik öğretmenlerinin nitelikli bir eğitim almasına bağlıdır. Türk müziği kültürünün aktarımı ve kanun, ud, bağlama gibi geleneksel çalgıların müzik öğretmenleri tarafından eğitiminin alınması ile ancak bu zincirin devamının sağlanabileceği düşünülmektedir. Kanun eğitiminin gerçekleşmesinin ise, müzik öğretmenleri programlarında geleneksel çalgılara yer verilmesi, yaygınlaştırılması ve nitelikli bir çalgı eğitimi ile büyük ölçüde sağlanacağı düşünülmektedir.

Kanun eğitimi günümüzde, Türk müziği devlet konservatuarlarında, eğitim fakülteleri müzik eğitimi anabilim dallarında, sanat ve tasarım fakültelerinde, güzel sanat fakültelerinde, belediye konservatuarlarında ders olarak verilmektedir. Kanun eğitiminin birçok kurum ve kuruluşlarda ders kapsamına alınması, okutulması literatüre yeni kaynakların ve metotların eklenmesini sağlamıştır.

Kanunun, geleneksel bir Türk müziği çalgısı olmasının yanında, solo ve eşlik çalgısı olması, komalı Türk müziği eserlerini seslendirebilme özelliğinin yanı sıra dünya müziklerini seslendirebilmedeki uyumu, geniş ses alanı, ses gürlüğü bakımından oldukça güçlü ve ahenkli sesi, taşınabilir ve süslü icraya yatkın olması gibi özellikleri düşünüldügünnde eğitim müziğinde kullanılabilirliği oldukça yüksek bir çalgı olarak düşünülmektedir. Kanunun tüm bu özellikleri dikkate alındığında okul çalgıları olarak bilinen ve halen üniversitelerin eğitim fakültelerinin müzik eğitimi anabilim dalları lisans programında yer alan, bağlama, gitar ve blok flüt gibi çalgılara yeni bir soluk ve alternatif oluşturabilecek bir yapıdadır. Kullanılış şekli bakımından piyano gibi bir solo ve eşlik çalgısı özelliklerini kendinde barındıran bu çalgının; eğitim müziğinde kullanılabilirliğinin önünün açılabilmesinin ancak eğitim müziğine aktarılmasıyla olacağı, bu çalgıyla ilgili yeni ürünlerin ve yeni kaynakların ortaya koyulması ile yaygınlaşacağı düşünülmektedir. Nitekim Kahyaoğlu (2011), kanunu Türk kültürünü ve Türk müziğini tanıtmada önemli yeri olan ve yapısı gereği her türlü teknik imkânlara sahip olan ve Batı müziği karakterini de yansıtan Türk müziğinin bir piyanosudur biçiminde aktarmıştır. Müzik eğitimi anabilim dallarında bireysel çalgı ve okul çalgıları derslerine alternatif olarak bu çalgının eğitiminin verilmesi doğrultusunda kanunun eğitim müziğinde yaygınlaşabileceği düşünülmektedir. Geleneksel kültürün ve müziğin en doğru şekilde genç kuşaklara aktarılabilmesi için müzik eğitiminde geleneksel çalgılar kullanılmalıdır (Kaçar, 2007). 
Alan yazın incelendiğinde kanunun ilköğretim müzik derslerinde öğrenci başarı ve tutumlarına yönelik çalışmaların olmadığı görülmüştür. Kanunun ilköğretim müzik derslerinde kullanımına yönelik araştırmalar ise son derece sınırlıdır. Alan yazında, Devecioğlu (2017) kanunu, ilköğretim 8. sınıf düzeyinde, müzik derslerinde kullandığ çalışması gözlenmektedir. Çalışmada, araştırmacı tarafından geliştirilen öğretim yaklaşımıyla müzik derslerinde, kanun eşliği ile etkililik düzeyi gözlenmiştir. İlköğretim düzeyinde kanunun kullanıldığı sınırlı sayıda çalışmalara karşın bu çalışma, kanunun ilköğretim müzik derslerindeki öğrenci başarı ve tutumlarına yönelik ilk olması açısından önemli bulunmaktadır.

Türk Sanat ve Halk müziği çalgıları kullanılarak yürütülen müzik derslerinin öğrenci başarısına ve tutumuna etkisi konusunda yapılan bu çalışma, iki farklı müzik türüne ait farklı özellikteki çalgıların müzik dersindeki kullanımıyla ilgili bir deneyi içerir. Nitelikli müzik dersi için, farklı örneklemlerle yürütülmüş, farklı değişkenleri sorgulayan, farklı çalgıları deneyen çalışmaların çeşitliliği gereklidir. Bu çalışmanın, ilköğretim düzeyinde, kanunun müzik derslerinde kullanıldığı son derece sınırlı araştırmalara yenilik getirmesi beklenmektedir. Çalışmada kullanılan değişkenlerden biri de tutumdur.

İlköğretim düzeyinde müzik başarı ve tutumlar üzerine çalışmalar mevcuttur (Afacan, 2010; Akgül, 2013: Akgün, 2018; Demir, 2014: Demirtaş, 2011; Gülsoy ve Bulut, 2016; Işık, 2008; İnceel, 2011; Kaçar, 2007; Koca, 2013; Kocaarslan, 2009; Kocabaş ve Selçioğlu, 2006; Kocabaş, 1997; Levent, 2013: Nacakçı, 2006; Otacığlu, 2007; Özmenteş, 2006; Öztopalan, 2007; Saruhan ve Deniz, 2011; Şahin ve Toraman, 2014; Uluocak, 2008: Uluocak ve Tufan, 2011; Umuzdaş ve Kızıklı, 2018; Umuzdaş, 2012; Üstün, 2014: Varış ve Cesur, 2012).. Bireyin davranışa hazırlayan ön eğilimlerinin, bireyin davranışları ile doğrudan bağlantı olması (Özmenteş, 2006: 25) tutum değişkenini araştırmacılar için önemli kılmaktadır.

Hedeflenen müziksel davranışın değiştirmesi tutuma bağlı ise müzik dersine yönelik tutumun geliştirilmesi, hedeflenen müzikal davranışa ulaşılmasını sağlayabilir. Erken yaşlarda edinilen ve birey üzerinde nispeten etki yaratan tutumların etkili ve güçlü olduğu görülmektedir. Bireylerin, özellikle çocukluk dönemindeki yaşantıları, hayatı boyunca yaşadığı başarılı ve başarısız deneyimler, sosyal ve toplumsal öğrenmeler tutum üzerinde önemli bir etkendir. Erken yaşlarda edinilen tutumların nispeten güçlü olduğu, kolay değişmediği ve düşünüldüğünde; tutumların değiştirilmesi ve yeni tutumların oluşması açısından erken yaşlarda edinilmesi bireye müzikal davranışların kazandırılması açısından önemlidir (Kağıtçıbaşı, 2010; Kocaarslan, 2009). 
Müzik dersi açısından bakıldığında derse yönelik olumlu ve olumsuz tutumlar, müziksel davranışı kolaylaştırabilen ya da davranışı engelleyebilen bir ön eğilim olarak ortaya çıkar. Olumlu tutumlar müzik dersi için istendik bir davranış olsa da, bireyin duygu, düşünce ve eğilimleri olumlu yönde olmayabilir. Bu durum gözlenebilir davranışlara yön verebilen bir değişken olabilir. Müzik dersine yönelik olumlu tutum gösteren bireyin, derse zamanında gelmesi, ilgi göstermesi, derse katılması gibi birbiriyle ilintili davranışlar gösterebilir. Olumlu tutum davranışta yordayıcı bir değişken olabilir. Müzik dersine yönelik olumsuz tutum içerisindeki birey ise olumlu tutumun aksine bireyde, istenmeyen durumların gözlenmesine sebep olacağı düşünülmektedir. Müzik dersine karşı ilgisiz kalması, devamsızlık göstermesi, istenmeyen davranışların ortaya çıkması ve müziksel davranışa ulaşmada yetersizlikler olumsuz tutum karşıtı davranışlar olarak gözlenebilir.

İlköğretim düzeyinde öğrencilerin müzik dersinde, müziksel bilgi beceri ve davranışları kazanmasında tutumlar büyük ölçüde rol oynamaktadır. Müziğe ve müzik dersine ilişkin olumlu ya da olumsuz tutumların ölçülmesi, değerlendirilmesi, olumlu tutumların geliştirilerek olumsuz tutumların ise mümkünse olumlu hale getirilmesi müzik dersi akademik başarısı açısından önemli bir etkendir. Akademik başarı ile tutum arasında güçlü bir bağ vardır. Öğrencinin müzik dersine olumlu tutumu dersin kalıcılığını etkileyerek öğrenme kolaylığı sağlar. Müzik dersi başarısını etkileyen tutumun, akademik başarının oluşmasında bir temel olduğu söylenebilir. Öztopalan (2007), tutum ile başarı arasında aynı yönde ve pozitif bir ilişki olduğunun altını çizerek, olumlu tutumlara sahip olan bir öğrencinin ders başarısının da yüksek olacağını belirtmiştir. Ayrıca ders başarısı yüksek öğrencinin derse tutumunun da yüksek olduğunu aktarmıştır.

Akademik başarıyı etkileyen birçok faktör vardır. Öğrenci, öğretmen, öğretimin niteliği, kullanılan materyaller, öğrenme iklimi ve sınıf fiziksel yapısı gibi faktörler öğrenmenin gerçekleşmesinde ve öğrencinin başarıya ulaşmasında önemli bir etkendir. Genellikle başarı, bireyin öğrenme yaşantıları sonucunda not gibi sayısal verilerle ifade edilir. Bir başka deyişle başarı, istenilen sonuca ulaşmak için adım adım kaydedilen bireydeki gelişme olarak da tanımlanabilir. İnceel (2011)'e göre başarı, amaçlanan bir işi istenilen şekilde sonlandırmak olarak ifade etmiştir (İnceel, 2011: 67). Tan’a göre başarı ise, öğrenme sürecindeki bireylerin, öğrenme faaliyetlerine ne düzeyde ulaştığının belirlenmesi olarak aktarmıştır (Tan, 1996; 19). Başarı, insan hayatının her aşamasında olan ve oldukça önemli görülen bir kavramdır. İnsan yapısı gereği yaptığı işi sonlandırmak, başarmak ve mutlu olmak ister. İnsan yaşamında başarı istenen bir gelişmedir. Ancak başarının yanında başarısızlık da 
insan yaşamının doğal bir parçasıdır. Bireyler, eğitim öğretim yaşamlarında başarı ve başarısızlığı genellikle öğrenme yaşantıları sonucunda aldıkları sayısal sonuçlara göre belirlerler. Akademik başarı, bilişsel yeterlilik ve beceri gerektiren derslerde öğrenme yaşantısı sonucuna dayanmaktadır. Derslerde kendinden isteneni yapan, ders çalışması sıklığı ve niteliği ile öne çıkan, dersin sınavlarından yüksek not alan öğrenci başarılı kabul edilir.

Eğitim öğretimin herhangi bir kademesinde, akademik başarı çeşitli şekillerde hazırlanan ve geliştirilen başarı testleriyle ölçülür. Akademik başarı, eğitimi verilen derslerin kazanımlarına ulaşıp ulaşılmadığının denetimi için ölçme ve değerlendirmeler ile belirlenir (Uyan, 2012: 16). Beceri ve kazanımların ölçülmesinde, akademik başarının belirlenmesinde başarı testleri, kullanımı gerekli ve önemli bir ölçüt olduğu söylenebilir. Başarı testleri, belli bir programa dayalı öğretimin ardından ölçülen, akademik olarak ne kadar gelişim gösterildiğinin belirlenmesine yönelik testlerdir (Yıldırım, 1999: 15).

Carter ve Good (1973)'a göre başarı, bireylerin okuldaki öğrenim gördüğü derslerde elde ettikleri kazanım ve becerilerin sonucunda, öğretmenlerce verilen notlarla ve yapılan testlerden aldıkları puanlarla ifade edilmesidir (Akt. Orhan, 2019: 4).

İlköğretim müzik dersi sürecinde, öğrencilerin başarısı; çalg1, nota gibi görsel ve işitsel materyallerle desteklenmesiyle dolaylı olarak sağlanabileceği düşünülmektedir. $\mathrm{Bu}$ etki; tutum, güdü, motivasyon gibi psikolojik olgularla olabilir. Alan yazın incelendiğinde, çalgı eşlikli müzik dersi uygulamalarının öğrenci tutumları üzerine etkisinin incelendiği çeşitli çalışmaların yapıldığı görülmektedir

Kanun ve bağlamayı karşılaştırarak, öğrencilerin müzik dersi başarılarını ve tutumlarını araştıran deneysel bir çalışma henüz yapılmamıştır. Yapılan bu araştırma, deney için seçilen çalgıların farklı müzik türlerine ilişkin olması yönüyle dikkat çekmekte, bir Türk halk müziği ve bir Türk sanat müziği çalgısını bu yönüyle aynı çalışmada kullanan ilk çalışma olması açısından da önemli görülmektedir.

$\mathrm{Bu}$ çalışmada, Türk sanat ve halk müziği çalgılarıyla yürütülen müzik dersi uygulamalarının ilköğretim öğrencilerinin ders başarı ve tutumlarına etkisini belirlemek amaçlanmıştır. Bu amaçla; bağlama ve kanun çalgılarıyla iki deney grubu ve çalgısız bir kontrol grubu ile uygulama yapılmıştır.

\section{Yöntem}

\section{Araştırmanın Deseni}


Türk halk ve sanat müziği çalgıları kullanılarak yürütülen müzik derslerinin, İlköğretim 6.sınıf öğrencilerinin ders başarı ve tutumlarına etkisi nedir? problemine yönelik deneysel müdahale ile kanun ve bağlama çalgılarının deney gruplarındaki etkisini belirlemektedir. Bu bağlamda öntest-sontest kontrol gruplu deneme modeli kullanılmıştır.

Deneme modelleri, neden-sonuç ilişkilerini belirlemeye yönelik araştırmacı kontrolünde gerçekleştirilen ve gözlenen verilerin üretiminin yapıldığı modelidir (Karasar, 2003). Bilimsel değeri en yüksek deneyler, gerçek deneme modeliyle yapılanlardır. Gerçek deneme modellerinin ortak özellikleri, Bir'den çok gruplu kullanılması ve grupların yansız atama (örnekleme) ile oluşturulmasıdır (Karasar, 2003). Bu çalışmada da, seçkisiz atanan kontrol ve iki deney grubuna öntest -sontest ölçümlerin yapılarak farklı çalgıların etkileri sınanmiştır.

Araştırma, aynı sayıda öğrenciden oluşan üç farklı sınıfta uygulanmıştır. Sınıflardan ikisi deney, biri ise kontrol grubu olarak oluşturulmuştur. Güz döneminde deney gruplarını oluşturan iki şubeden rastgele birine kanun diğer şubeye ise bağlama kullanılarak müzik dersi yürütülmüştür. Kontrol grubuna ise çalgı kullanılmadan deney gruplarıyla aynı içeriğe sahip öğretim süreci işlenmiştir.

2018-2019 eğitim öğretim yılı müzik dersi ünitelerinden altı tanesi ilköğretim 6. sınıf ders müfredatı öğretim programı ve yardımcı kaynaklar taranarak belirlenmiştir. Bu konular, öğrencilerin günlük yaşamında işlevselliği olan, bilişsel başarı testi ile ölçülebilecek bilişsel kazanımları içerir.

İlköğretim 6. sınıf müzik dersi öğretim programında yer alan; müziklerde hız değişiklikleri, müzikte gürlük değişiklikleri, yurdumuza ait başlıca müzik türleri, Türk müziğinde makamsal yapı, ses değiştirici işaretler ve Atatürk ve müzik üniteleri ile 08.10.2018 ve 28.12.2018 tarihleri arasında 12 haftalık sürede yürütülmüştür.

Uygulama öncesinde, araştırmanın yapılacağı Turhal İbni Sina İlköğretim Okulu Müdürlüğü ile görüşülmüş, gerekli izinler Tokat İl Milli Eğitim Müdürlüğü ve Tokat Valiliğinden Ekim 2018 - Haziran 2019 tarihleri arasında alınmıştır.

\section{Çalışma evreni}

Araştırmada evreni 2018-2019 eğitim-öğretim yılı güz döneminde, Tokat İli Turhal İlçesinde bulunan Millî Eğitim Bakanlığına bağlı İbni Sina İlköğretim Okulunda eğitimine devam eden 48 (24 kız, 24 erkek) altıncı sınıf öğrenci oluşturmaktadır. 
Araştırmaya, 15 öğrenci A şubesinde, 18 öğrenci B şubesinde, 15 öğrenci C şubesinde olmak üzere toplam 48 öğrenci katılmıştır. Grupların \%31.25 ini A şubesi, \%37.5 ini B şubesi, \%31.25 ini C şubesi oluşturmaktadırlar.

\section{Veri Toplama Araçları}

Araştırmanın amaçları doğrultusunda, müzik dersine yönelik tutumlarının ölçülmesi için “Umuzdaş İlköğretim Müzik Dersi Tutum Ölçeği” ve kazanımları ölçmek için “ Kızıklı 6. Sınıf Müzik Başarı Testi” kullanılmıştır.

\section{İlköğretim Müzik Dersi Tutum Ölçeği}

Umuzdaş (2012) "Müzik Dersine İlişkin Tutum Ölçeği (MTÖ)" 5 seçenekli ve 5 faktörlü 28 maddelik bir ölçektir. Ölçek, Antalya’da bulunan üç farklı ilköğretim okulunda yer alan 6. 7. sınıf 692 öğrenciye uygulanarak geliştirilmiştir. Ölçeğin Kaiser-Meyer Olkin(KMO) değeri 0,94, Cronbach Alpha. 90'dır. Ölçekten alınabilecek en düşük tutum puan1 28 , en yüksek puan ise 140 'tır.

\section{Müzik Başarı Testi}

Başarı testi, Kızıklı tarafından, bu araştırmada kullanılmak üzere, İlköğretim 6.sınıf öğrencilerine yönelik belirlenen konular kapsamında müzik dersi kazanımlarının ne düzeyde gerçekleştiğinin ölçülmesi amacıyla hazırlanmıştır.

Deney ve kontrol gruplarına çalışma öncesi ve sonrasında uygulanan başarı testinin kapsamını oluşturan konular: İlköğretim 6. Sınıf müzik dersi konularından belirlenmiş, Müziklerde Hız değişiklikleri, Müzikte Gürlük Değişiklikleri, Yurdumun Ait Başlıca Müzik Türleri, Türk Müziğinde Makamsal Yapı, Ses Değiştirici İşaretler, Atatürk ve Müzik konuları seçilmiştir.

Müzik dersine yönelik dört seçenekli, 30 sorudan oluşan başarı testi, geçerlilik ve güvenirlik çalışması yapmak amacıyla 100 öğrenciye uygulanmıştır. Testin KMO değeri 0.753, Bartlett's testinin anlamlı olmasıyla $(\mathrm{P}<$. 0.5) 100 kişilik örneklem büyüklüğünün yeterli olduğu anlaşılmıştır. Bu çalışmada testten öğrencilerin aldığı puanların güvenirliğini belirlemek için Cronbach Alfa değeri a $=0.869$ 'dur.

\section{Verilerin Çözümlenmesi}

Araştırmada elde edilen veriler 1şı̆̆ında nicel verilerin çözümlenmesi ve yorumlanması amacıyla veriler bilgisayara aktarılmış ve istatiksel çözümler için paket program kullanılmıştır. Öğrencilerden, Müzik Dersi Başarı Testi ve Müzik Dersi Tutum Ölçeği ile elde edilen verilerin analizinde SPSS 22.0 (Sosyal Bilimler için İstatistik Programı) Mann Whitney U, Shapiro-Wilks, Kruskall-Wallis Varyans testleri kullanılmıştır. Deney ve 
kontrol gruplarının tüm hesaplamalarında istatiksel anlamlılık düzeyi için .05 olarak belirlenmiştir.

Grupları oluşturan öğrencilerin başarı puanları üzerinde uygulanan normallik testi hesaplamaları için Shapiro- Wilk-U, Kolmogorov- Simirnov(a) non parametrik olan yöntemler kullanılmıştır. Grupların normal dağılım göstermesine rağmen grupların 30'dan küçük olması sebebiyle non-parametrik yöntemler kullanılarak verilerin hesaplanmasına karar verilmiştir.

Deney ve kontrol grubu öğrencilerine uygulanan Müzik Dersi Başarı Testi ve Müzik Dersi Tutum Ölçeği sonuçlarının öntest ve sontest puanlarının değişkenlere göre farkl11ık gösterip göstermediğini tespit etmek için yapılan ölçümlerde Mann Whitney U testi kullanılmıştır.

\section{Bulgular}

Tablo 1. Deney Grubu ve Kontrol Grubu Öğrencilerinin Başarı Puanları Üzerinde Uygulanan Normallik Testi Sonuçları

\begin{tabular}{lcccccc}
\hline & \multicolumn{3}{c}{ Kolmogorov-Smirnov(a) } & \multicolumn{3}{c}{ Shapiro-Wilk } \\
\hline & İstatistik & $\mathrm{df}$ & $\mathrm{p}$ & Statistic & $\mathrm{df}$ & $\mathrm{p}$ \\
\hline Kanun-Deney &, 283 & 15 &, 002 &, 814 & 15 &, 006 \\
Bağlama-Deney &, 191 & 15 &, 082 &, 925 & 20 &, 161 \\
& & & & & & \\
Kontrol &, 222 & 15 &, 045 &, 913 & 15 &, 150 \\
\hline
\end{tabular}

Yapılan Shapiro-Wilk testine göre kanun ve kontrol grubu öğrencilerinin başarı puanlarına göre anlamlılık düzeyi 0.05 'den küçük olduğundan her iki grubun da notlarının normal dağılıma sahip olmadığını gözlenmiştir. Yalnızca Bağlama grubu öğrencilerinin başarı puanlarına göre anlamlılık düzeyi yüksek çıktığı görülmüştür. Grupların 30'dan küçük olması sebebiyle non-parametrik yöntemler kullanılarak verilerin hesaplanmasına karar verilmiştir.

Tablo 2. Deneklerin (Kanun-Kontrol) Müzik Dersi Başarı Durumuna Göre Mann Whitney-U Testi

\begin{tabular}{lccccc}
\hline Grup & $\mathrm{n}$ & $\begin{array}{c}\text { Sira } \\
\text { Ortalamas } \\
1\end{array}$ & $\begin{array}{c}\text { Sira } \\
\text { Toplam } \\
1\end{array}$ & $\mathrm{U}$ & $\mathrm{P}$ \\
\cline { 1 - 4 } Deney(Kanun) & 15 & 17,07 & 256,00 & 89,00 & 0.324 \\
\cline { 1 - 3 } Kontrol & 15 & 16,43 & 209,00 & 0 & \\
\cline { 1 - 3 } & 15 & & & \\
\hline
\end{tabular}

Deneklerin müzik dersi başarı testi sıra ortalamaları arasında 0,64'lük fark olduğu görülmektedir. Mann Whitney $U$ testi sonucunda öğrencilerin başarı testi notları arasında anlamlı bir fark bulunmamaktadır $(U=89,000$ p>0.05). Bu sonuca göre kanun ile işlenen derslerle, kontrol grubuyla işlenen dersler arasında bir fark olmadığı görülmektedir. 
Tablo 3. Deneklerin(Bağlama-Kontrol) Müzik Dersi Başarı Durumuna Göre Mann WhitneyU Testi Tablosu

\begin{tabular}{|c|c|c|c|c|c|}
\hline Grup & $\mathrm{n}$ & $\begin{array}{c}\text { S1ra } \\
\text { Ortalamas } \\
1\end{array}$ & $\begin{array}{c}\text { Sira } \\
\text { Toplam } \\
1\end{array}$ & $\mathrm{U}$ & $\mathrm{P}$ \\
\hline Deney (Bağlama) & $\begin{array}{l}1 \\
8\end{array}$ & 19,56 & 352,00 & $\begin{array}{c}89,00 \\
0\end{array}$ & 0.091 \\
\hline Kontrol & $\begin{array}{l}1 \\
5\end{array}$ & 13,93 & 209,00 & & \\
\hline
\end{tabular}

Tablo 4. Deneklerin (Kanun-Kontrol) Müzik Dersi Tutum Puanlarına Göre Mann Whitney-U Testi Tablosu

\begin{tabular}{lccccc}
\hline Grup & $\mathrm{n}$ & $\begin{array}{c}\text { Sira } \\
\text { Ortalamas } \\
1\end{array}$ & $\begin{array}{c}\text { Sira } \\
\text { Toplam } \\
1\end{array}$ & $\mathrm{U}$ & $\mathrm{P}$ \\
\cline { 1 - 4 } Deney(Kanun) & 1 & 15,90 & 238,50 & $\begin{array}{c}106,50 \\
0\end{array}$ & 0.802 \\
\cline { 1 - 3 } & 5 & & & 0 & \\
\hline Kontrol & 1 & 15,10 & 226,50 & & \\
& 5 & & & & \\
\hline
\end{tabular}

Deneklerin müzik dersi tutum puanları sıra ortalamaları arasında 0,80'lik bir fark görülmektedir. Ancak öğrencilerin tutum puanları arasında anlamlı bir farklılık bulunamamıştır $(\mathrm{U}=106,500 \mathrm{p}>0.05)$. Bu sonuca göre kanun ile kontrol gruplarının tutumları arasında bir farkın anlamlı olmadığı görülmektedir.

Tablo 5. Deneklerin(Bağlama-Kontrol) Müzik Dersi Tutum Puanlarına Göre Mann WhitneyU Testi Tablosu

\begin{tabular}{lccccc}
\hline Grup & $\mathrm{n}$ & $\begin{array}{c}\text { Sira } \\
\text { Ortalamas } \\
1\end{array}$ & $\begin{array}{c}\text { Sira } \\
\text { Toplam } \\
1\end{array}$ & $\mathrm{U}$ & $\mathrm{P}$ \\
\cline { 1 - 4 } Deney(Bağlama) & 1 & 17,39 & 313,00 & 128,00 & 0.79 \\
& 8 & & & 0 & 9 \\
\cline { 1 - 4 } Kontrol & 1 & 16,53 & 248,00 & & \\
\cline { 1 - 3 } & 5 & & & & \\
\hline
\end{tabular}

Deneklerin müzik dersi tutum puanları sıra ortalamaları arasında 0,86'l1k bir fark görülmektedir. Ancak bağlama ve kontrol grubu tutumları arasında anlamlı bir fark olmadığı görülmektedir. 


\section{Sonuç, Tartışma ve Öneriler}

Araştırmalardan elde edilen sonuçlar, ilköğretim müzik derslerinde çalg1 kullanılarak işlenen müzik derslerinin öğrencilerin başarılarına ve derse yönelik ilgilerine olumlu etki ettiğini göstermektedir. Ancak bu çalışmada; deney grupları ve kontrol grubu ile yapılan müzik dersleri arasında başarı ve tutum bakımından anlamlı bir farka rastlanmamıştır.

Araştırmadan elde edilen sonuçlara göre, ilköğretim altıncı sınıf müzik dersi uygulamalarının herhangi bir çalgı kullanılmadan yürütülmesinin, öğrencinin başarı ve müzik dersi tutumunu etkilemediği anlaşılmaktadır. Öğrencilerin tutum ve başarı puanları, çalgı kullanılması ya da kullanılmaması ile yapılan öğretimlerden anlamlı şekilde etkilenmemiştir. Ortalamalara göre kontrol grubu öğrencilerinin tutum ve başarıları, uygulama sonrasında gelişme gösterse de, çalgı kullanılmadan öğretim yapmanın öğrenci başarı ve tutumuna istatistiki olarak etkisinden söz edilememektedir. Alan yazın incelendiğinde, çalgı eşlikli müzik dersi ile beraber etkililiği sınanan ve herhangi bir çalgı kullanılmadan uygulama yapılan kontrol gruplarının olduğu yöntem olarak benzer çalışmalar görülmektedir (Akgül, 2013; Altıntaş, 2007; Küçükosmanoğlu, 2011). Sonuçlarına genel olarak bakıldığında; çalg1 kullanılarak yürütülen müzik derslerinin herhangi bir çalgı kullanılmadan yürütülen gruplara göre müzik dersi başarı ve tutumlara daha etkili olduğu görülmektedir. Yılmaz (2010), çalg1 eşlikli müzik dersinin herhangi bir çalg1 kullanılmadan yürütülen müzik dersine göre öğrencilere öğretilen şarkıların daha kolay öğretilmesi ve müzik dersinin zevkli hale gelmesi bakımından tercih edildiğini ifade etmektedir. Herhangi bir çalgı kullanılmadan, sadece anlatım yöntemiyle yürütülen müzik derslerinin etkililiği sınırlı olabilmektedir. Literatüre göre; müzik dersinin doğası gereği kullanılan çalgılar öğrencilerin tutumlarını ve başarılarını olumlu yönde etkileyebilmektedir. Öztürk (2001)'ün yaptığı çalışma, müzik öğretmenlerinin çeşitli sebepler nedeniyle çalgılarını kullanamamasının sonucunda müzik dersi kazanımlarına ulaşmada yetersizlik yaşadığını ortaya koymaktadır. Bu çalışmada da çalgı kullanılmayan gruptaki ortalama değerlerin literatür ile uyumundan bahsedilebilir. Bu çalışmada ortalama değerler açısından istatistiki anlam tespit edilmese de, müzik derslerinde kullanılan çalgıların, ilköğretim öğrencilerinin müzik dersi başarı ve tutumlarına belirli bir düzeyde fark yarattığı görülmektedir.

Görülmektedir ki ilgili tüm çalışmalar, müzik dersinde çalgı kullanmanın, çalgı kullanmamaya göre tercih edilmesi gereğini bulgulamaktadır. Ancak hangi çalgının daha işlevsel olduğu sorusunu kesin olarak yanıtlamak güçtür. Her araştırmacı, çalışma sınırlığında 
deneyler yaparak genel bir bakış açısı oluşturma çabasındadır. Bu çalışma da aynı şekilde, müzik öğretmeni yetiştiren kurumların olağan şekilde "okul çalgısı" olarak verdiği çalg1 eğitimine alternatif üreterek, geçmişten günümüze her daim var olan tartışmayı devam ettirmektedir. Çalışmalar belli yönleriyle benzerlik ya da farklılık arz etmektedir. Farklı şehirlerde, farklı örneklemlerle, farklı sınıf düzeylerinde çalışmak çeşitli sonuçları doğurabilmektedir. Örneğin; Demirtaş, (2011) 7. sınıf öğrencilerine piyano eşlikli müzik dersi uygulamalarının ilgi ve başarıyı artırdığını gözlemlemiştir. Acar, (2009) ise, blok flütün programındaki kazanımlara ulaşmada istatistiki açıdan anlamlılık göstermediğini bulgulamıştır.

Demir (2014) benzer bir çalışmayla, bu çalışmada da deneyle sınanan bağlama çalgısıyla ilgili görüş toplamıştır. Bağlamanın eğitim müziğinde kullanımı ile ilgili olumlu görüşlerin varlığı anlaşılmaktadır. Bu araştırma bulguları anlamlı farklılık kaydetmese de ortalama değerler, bağlama kullanımını ilköğretimde kullanılmasının tutum ve başarı gelişimi bakımından işlevsel olduğunu gösterebilmektedir. Demir (2014) ve yine Akgül, (2013) 'ün araştırmaları bulguları ve bu çalışma ile paraleldir.

$\mathrm{Bu}$ araştırmanın sonuçlarına göre kanun ve bağlama çalgıları kullanılarak yürütülen müzik dersi uygulamalarında, belirlenen kazanımlara ulaşma durumuna bakıldığında istatistiki olarak anlamlı bir fark bulunmamakla birlikte, istendik yönde ilerleme kaydedildiği tespit edilmiştir. Başarı ön test ve son test sonuçları incelendiğinde; kanun ve bağlama çalgısıyla yürütülen gruplarda, öğrencilerin müzik dersi başarı testi sonuçları arttığı görülmektedir. $\mathrm{Bu}$ durum her iki çalgının da müzik dersi uygulamalarında kullanımının işlevsel olduğunu gösterebilir. Üstün (2014)'ün çalışması bu araştırmaya benzerlik göstermekle birlikte; bahsi geçen çalışmada çalgı olarak, bağlama, gitar ve blok flüt kullanmıştır. Seçilen çalgıların kazanımlara ulaşmada genel anlamda etkili olduğu belirtilmiştir. $\mathrm{Bu}$ araştırma ile Üstün'ün yaptı̆̆ı çalışma sonuçları incelendiğinde; müzik dersinde kullanılan çalgıların belirlenen kazanımlara ulaşmada istatistiki açıdan anlamlılık farklılık olmaması ancak öğrenci başarılarına istendik yönde ilerleme kaydedilmesi açısından benzerlik görülmektedir.

$\mathrm{Bu}$ araştırmanın sonuçlarına göre; bağlamayla aynı şekilde kanunun da başarı ve tutuma etki etmediği görülmüştür. Öğrencilerin tutum puanlarına göre anlamlı bir fark bulunmasa dahi öğrenci tutumlarında istendik yönde gelişme kaydedildiği tespit edilmiştir. Öğrenci tutum puanlarının her iki çalgının uygulandığı gruplarda arttığı, öğrencilerin derse 
olan ilgileri ve katılımların yüksek oranda olduğu görülmüştür. Bağlama ve kanun bu bakımdan karşılaştırıldığında ise bağlama lehine bir sonuç elde edilmektedir.

Geleneksel çalgıların eğitim müziğinde kullanılmasının, kültürün yeni nesillere aktarılmasında önemli bir rolü bulunmaktadır. Geleneksel çalgıların ilköğretim müzik derslerinde kullanımın, bilinenden bilinmeye ve yakından uzağa eğitim ilkelerini uygulanmasını ve öz müziğin en doğru bir şekilde aktarılmasını sağlayabilir. Öğrencilerin müzik derslerinde bağlama ve kanun gibi geleneksel çalgıları görmesi, çalgılara ya da derse ilgiyi arttırabileceği düşünülmektedir. Kaçar (2007) ud için ve Işı (2008) da bağlama için benzer düşünceler dile getirmiştir.

Türk sanat müziğinde kullanılan çok telli ve mızraplı bir çalgı olan kanun bütün parmaklar kullanılarak çalınan ve içerisinde çok sesliliği barındıran bu çalgı yapılan çalışmalarda çalım şekli ve işlevselliği bakımından piyano ve gitara benzetilmektedir (Devecioğlu, 2017; Doğruöz, 2017; Savaş, 2016; Kahyaoğlu, 2011). Eğitim müziği içerisinde işlevselliği kabul görmüş olan piyano gibi bir çalgıya benzetilmesi, araştırmacıları kanunun işlevselliğini sorgulamaya itmektedir. Eğitim müziği içerisinde yer alan müzik dağarının seslendirilmesini sağlayabilen kanunun tampere ve komalı sesler bulunduran eserleri seslendirmede sorun yaşamadığı bu çalışmanın deney sürecindeki kayıtlarda açıkça görülmüştür. Yapılan araştırma doğrultusunda ve öğrencilerin tutum ve ders başarılarına istatistiki olarak etkisi bulunmamıştır. Ancak deney sürecinde alınan kayıtlar ve ortalama değerler, kanunun müzik eğitiminde kullanılabilirliğini ortaya koymaktadır. Geçmişe ve güncel duruma bakıldığında kanunun ilköğretim müzik eğitiminde yeri çok sınırlı olmuş, ancak kanun gibi TSM çalgılarının öğretimde kullanılması konusu alanda ilgi ve merak uyandırmıştır. Demir, (2007)'in çalışmasında çalgı olarak udun denenmesi bu ilgi ile başlamıştır. Demir; ud eşliğinde işlenen müzik derslerine öğrenci katımlarının ve derse yönelik ilgilerinin arttırdığını belirtmiştir. Buradan hareketle; konu ve ton özelliğine göre derslerde farklı ve uygun çalgıları bizzat kullanmak ya da sazendeleri derse misafir etmek de düşünülebilir.

Kanun, bağlama ve çalgı kullanılmadan yürütülen müzik uygulamaları sonucunda öğrencilere uygulanan başarı testi puanlarının bağlama lehine yüksek olduğu belirlenmiş, bağlamanın kanun ve herhangi bir çalgı kullanılmayan gruba göre daha işlevsel bir çalgı olduğu anlaşılmıştır. Üstün (2014) tarafindan yapılan çalışma ile yapılan araştırmanın bağlamanın kullanımının öğrencilerin başarı durumları üzerindeki bulgularının benzerlik taşıdığı görülmektedir. $\mathrm{Bu}$ araştırma ve yapılan çalışma sonucunda müzik derslerinde 
kullanılan bağlamanın öğrencilerin başarı seviyelerini arttırması, bağlama çalgısının işlevsel bir çalgı olduğu sonucunu ortaya koyar. Üstün’ün çalışmasında müzik derslerinde kullanılan bağlama ile bu araştırmada THM çalgılarından bağlama kullanımın öğrenciler üzerinde olumlu etkileri bakımından benzerdir. Literatür sonuçları ile bu araştırma sonuçları uyumludur. Tüm çalışma gruplarında, öğrencilerin tutum puanları başarı testinden ayrı olarak incelendiğinde, ortalama tutum puanları uygulama öncesi ve sonrasında tutum testlerinden alınan puanların anlamlı olmadığı ancak uygulama öncesi ve sonrasında alınan tutum puanlarında bir artışın olduğu görülmektedir. Bağlama ve kanun çalgılarının kullanıldığı sınıflarda 12 hafta boyunca süren uygulama süresince öğrencilerin ilgilerinin, derse devamın ve katılımın yüksek olduğu gözlenmiştir.

Eğitim fakültesi ve müzik öğretmeni yetiştiren kurumlar bünyesinde okul çalgıları ve bireysel çalgı derslerinde eğitimi verilen çalgılar, bu ve benzeri çalışmalara göre şekil verilebilir ve çeşitli THM ve TSM çalgıları kullanılarak, farklı öğrenci grubu ve konu alanlarında deneysel çalışmalar yapılması çeşitli değişkenler dâhilinde çeşitlendirilmesi önerilebilir.

\section{Makalenin Bilimdeki Konumu}

Müzik Eğitimi ABD, Devlet Konservatuvarı

\section{Makalenin Bilimdeki Özgünlüğü}

Kanun ve bağlamayı karşılaştırarak, öğrencilerin müzik dersi başarılarını ve tutumlarını araştıran deneysel bir çalışma henüz yapılmamıştır. Yapılan bu araştırma, deney için seçilen çalgıların farklı müzik türlerine ilişkin olması yönüyle dikkat çekmekte, bir Türk Halk Müziği ve bir Türk Sanat Müziği çalgısını bu yönüyle aynı çalışmada kullanan ilk çalışma olması açısından da önemli görülmektedir. 


\section{Kaynaklar}

Acar, M. A. (2009). Bir sınıf çalgısı olarak blok flütün ilköğretim müzik dersi öğretim programını gerçekleştirebilmedeki yeterliliği. (Yayımlanmış yüksek lisans tezi). Cumhuriyet Üniversitesi, Sosyal Bilimler Enstitüsü, Sivas.

Acar Önal, A. ve Aydoğan S. (2012). Bir sınıf çalgısı olarak blok flütün ilköğretim müzik dersi öğretim programını gerçekleştirebilmedeki yeterliliği: Süleyman Demirel Üniversitesi Güzel Sanatlar Fakültesi Hakemli Dergisi. 10, 57 -76.

Afacan, Ș. (2010). Illköğretim ikinci kademe öğrencilerinin müzik dersine yönelik öz yeterlilik algı ve tutumlarının değerlendirilmesi. (Yayımlanmış yüksek lisans tezi). Gazi Üniversitesi, Eğitim Bilimleri Enstitüsü, Ankara.

Akgül, B. (2013). Enstrüman eşlikli uygulamaların ilköğretim 6. sınıf öğrencilerinin müzik dersine yönelik başarı ve tutumlarına etkisi. (Yayımlanmış doktora tezi). Marmara Üniversitesi, Eğitim Bilimleri Enstitüsü, İstanbul.

Akgün, E. (2018). Ortaöğretim Müzik Dersinde Kullanılan Blok flüt ve Melodika Çalgılarının Öğrenci Performansları Üzerindeki Etkililik Düzeylerinin Karşılaştırılması. (Yayımlanmış Yüksek Lisans Tezi). Erzurum: Atatürk Üniversitesi Eğitim Bilimleri Enstitüsü Güzel Sanatlar Eğitimi Ana Bilim Dalı Müzik Öğretmenliği Bilim Dalı.

Altıntaş, B. (2007). Illköğretim okullarında 6. sınıf müzik derslerinde verilen mandolin eğitiminin müzik dersi başarısı üzerine etkileri. (Yayımlanmış yüksek lisans tezi). Marmara Üniversitesi, Eğitim Bilimleri Enstitüsü, İstanbul.

Demirtaş, S. (2011). İlköğretim 7. sınıf müzik dersinde şarkıların piyano eşlikli öğretilmesinin öğrenci kazanımlarına etkileri. (Yayımlanmış yüksek lisans tezi). Pamukkale Üniversitesi, Sosyal Bilimler Enstitüsü, Denizli.

Demir, M. (2014). Ortaokul 6. 7. ve 8. sinıf öğrencilerinin müzik derslerinde bă̆lama çalgısının kullanımına ilişkin görüşleri. (Yayımlanmış yüksek lisans tezi). Mehmet Akif Ersoy Üniversitesi, Eğitim Bilimleri Enstitüsü, Burdur.

Devecioğlu, N, D. (2017). Kanun çalgısının okul müzik eğitiminde kullanımına yönelik geliştirilen sistematik yaklaşımlar ve etkililik düzeyleri. (Yayımlanmış yüksek lisans tezi). Atatürk Üniversitesi, Eğitim Bilimler Enstitüsü, Erzurum.

Doğruöz, M., D. (2017). Müzik öğretmenliği lisans programlarında yer alan bireysel çalg1 dersi kapsamında "kanun". Ege Üniversitesi Devlet Türk Musikisi Konservatuvart Dergisi. 2017 (11), 63-72. 
Ergen, (2010). Illköğretim düzeyinde eşlikli çalmaya dayalı keman ĕgitiminin entonasyon, özgüven ve tutum üzerindeki etkisi. (Yayımlanmış doktora tezi). Dokuz Eylül Üniversitesi, Eğitim Bilimleri Enstitüsü, İzmir.

Emnalar, A. (Nisan, 1993). Türk halk müziğinin eğitimdeki yeri. 1. ulusal müzik eğitim sempozyumu, Trabzon,

Gülsoy, Y., ve Bulut, D. (2016). Ortaokul müzik dersine yönelik veli görüşleri (niğde ili örneği). Journal of Human Sciences. 13(3), 4944-4958. doi:10.14687/jhs.v13i3.4138 adresinden alınmıştır.

Göğüş, G. (2008). İlköğretim I. kademe müzik eğitiminde öğretmenin etkinliği. Uludăg Üniversitesi Ĕ̆itim Fakültesi Dergisi. 21(2), 369-382.

Halvaşi, B , Akgül, A , Özbek, Ö . (2017). Enstrüman eşlikli uygulamaların ilköğretim öğrencilerinin müzik dersine ilişkin tutumlarına ve başarılarına etkisi. Trakya Üniversitesi Sosyal Bilimler Dergisi. 19(2), 217-233. http://dergipark.org.tr/trakyasobed/issue/33347/371296 adresinden alınmıştır.

Iş1k, H. (2008). İlköğretim ve ortaöğretimde görev yapan müzik öğretmenlerinin bă̆lama kullanımlarının incelenmesi. (Yayımlanmış yüksek lisans tezi). Gazi Üniversitesi Eğitim Bilimleri Enstitüsü, Ankara.

İnceel, S. (2011). İlköğretim öğrencilerinin müzik dersine ilişkin tutumları ile türkçe ve müzik dersleri akademik başarıları arasındaki ilişkinin incelenmesi. (Yayınlanmış yüksek lisans tezi). Marmara Üniversitesi, Eğitim Bilimleri Enstitüsü, İstanbul.

Kaçar, G. Y. (2007). Geleneksel çalgılardan udun müzik öğretmenliğinde kullanılması. Erciyes Üniversitesi Sosyal Bilimler Dergisi. 22(1), 111-121.

Karasar, N. (2003). Bilimsel araştırma yöntemi. Ankara: Nobel Yayınevi.

Kağıtçıbaşı, Ç. (2010). Günümüzde insan ve insanlar. İstanbul: Evrim Yayınevi.

Kahyaoğlu, Y. (2011). Kanun sazı ögrretiminde klasik türk müziği saz eseri formlarının fonksiyonlarının incelenmesi. (Yayımlanmış doktora tezi). İnönü Üniversitesi, Sosyal Bilimler Enstitüsü, Malatya.

Koca, Ş. (2013). Ortaöğretim öğrencilerinin müzik dersine yönelik tutumlarının incelenmesi. Ç.Ü. Sosyal Bilimler Enstitüsü Dergisi. 22(2), 209-222.

Kocaarslan, B. (2009). Genel müzik ĕgitimi alan ilköğretim öğrencilerinin müzik dersine ilişkin tutum, müzikal özgüven ve motivasyon düzeylerinin karşılaştırılmasl. (Yayımlanmış yüksek lisans tezi). Marmara Üniversitesi, Eğitim Bilimleri Enstitüsü İstanbul. 
Kocabaş, A. (1995). İşbirlikli öğrenmenin blok flüt ögrretimi ve ögrenme stratejileri üzerine etkileri. (Yayınlanmış doktora tezi). Dokuz Eylül Üniversitesi, Sosyal Bilimler Enstitüsü, İzmir.

Kocabaş, A. (1997). Temel eğitim II. kademe öğrencileri için müziğe ilişkin tutum ölçeğinin geçerlik ve güvenirlik çalışması. Hacettepe Üniversitesi Eğitim Fakültesi Dergisi. 13, 141-145.

Kocabaş, A. ve Selçioğlu, E. (2006). İlköğretim okulları 4. ve 5. sınıflarında müzik dersini gerçekleşme düzeyi ve öğrencilerin beklentilerine ilişkin görüşleri. Pamukkale Üniversitesi Eğitim Fakültesi Dergisi. 1(19), 58-68.

Küçükosmanoğlu, O. (2011). İlköğretim ikinci kademe şarkı öğretiminde kullanılan eşlik çalgılarının etkililiğinin karşılaştırılması. (Yayımlanmış doktora tezi). Selçuk Üniversitesi, Eğitim Bilimleri Enstitüsü, Konya.

Levent, A. (2013). İlköğretimde Müzik Öğretmeninin Kullandığı Çalgının Öğrencinin Derse ilişkin Tutumuna Etkisi. (Yayımlanmış Yüksek Lisans Tezi). Tokat: Gaziosmanpaşa Üniversitesi, Eğitim Bilimleri Enstitüsü, İlköğretim Anabilim Dalı, Sınıf Öğretmenliği Bilim Dalı.

Nacakçı, Z. (2006). İlköğretim Öğrencilerinin Müzik Dersine İlişkin Tutumları. Ulusal Müzik Eğitimi Sempozyumu Kitabı, Düzenleyen Pamukkale Üniversitesi, Denizli. 26-28 Nisan 2006.

Orhan, M. (2019). Animasyon destekli öğretimin öğrencilerin müzik dersi akademik başarısına etkisinin incelenmesi. (Yayımlanmış yüksek lisans tezi). Gazi Üniversitesi, Eğitim Bilimleri Enstitüsü, Ankara.

Otacıoğlu, S. G. (2007). İlköğretim 5. 6. 7. sınıf öğrencilerinin müzik dersine ilişkin tutumlarının incelenmesi. Dokuz Eylül Üniversitesi Buca Eğitim Fakültesi Dergisi. 21, 134-139.

Öztopalan, E. (2007). İlköğretim düzeyindeki özel okullar ile devlet okullarının 6, 7 ve 8. sinıf öğrencilerinin müzik dersine ilişkin tutumları ve akademik başarıları arasındaki ilişki. (Yayımlanmış yüksek lisans tezi). Dokuz Eylül Üniversitesi, Eğitim Bilimleri Enstitüsü, İzmir.

Öztürk, G. (2001). İlköğretim kurumlarında görev yapmakta olan müzik öğretmenlerinin çalgılarını kullanmadaki yeterlilik durumları. (Yayımlanmış yüksek lisans tezi). Gazi Üniversitesi, Eğitim Bilimleri Enstitüsü, Ankara. 
Özmenteş, G. (2006). Müzik dersine yönelik tutum ölçeğinin geliştirilmesi. İlköğretim Online Dergisi: 5(1), 23-29. [Online]: http://ilkogretim-online.org.tr adresinden alınmıştır.

Saruhan, Ş. ve Deniz, J. (2011). Temel eğitim II. kademe öğrencilerinin müzik dersine karş1 tutumları. Illkögretim Online Dergisi. 10(2), 695-702. [Online]: http://ilkogretimonline.org.tr adresinden alınmıştır.

Savaş, K. (2016). Mesleki müzik ĕgitimi veren devlet konservatuarlarındaki kanun ĕgitiminin içerik ve yöntem bakımından incelenmesi. (Yayınlanmış yüksek lisans tezi). Afyon Kocatepe Üniversitesi Sosyal Bilimleri Enstitüsü, Afyonkarahisar.

Şahin A. ve Toraman M. (2014). İlköğretim müzik dersine yönelik veli ve öğrenci görüşleri. Abant İzzet Baysal Üniversitesi Eğitim Fakültesi Dergisi. 14(1), 329-345.

Tan, H. (1996). Verimli ders çalışma ve hayata hazırlama. İstanbul: Alkım Yayınevi.

Tunalığlu, Ş. (2006). İlköğretim ikinci kademe okullarındaki müzik derslerinde yapılan düzenli çalgı ve ses eğitimi uygulamalarının öğrenciler üzerindeki etkisi. Marmara Üniversitesi. Atatürk Eğitim Fakültesi Eğitim Bilimleri Dergisi. 24, 179-203.

Uluocak, S. (2008). Gitarın öğretmen çalgısı olarak kullanımının ilköğretim öğrencilerinin müzik dersi başarısına etkisi. (Yayımlanmış doktora tezi). Gazi Üniversitesi, Eğitim Bilimleri Enstitüsü, Ankara.

Uluocak, S. ve Tufan, E. (2011). İlköğretim altıncı sınıf öğrencilerinin müzik dersine ilişkin tutumlarının farklı değişkenler açısından incelenmesi. Kastamonu Ĕ̆itim Dergisi. 19 (3), 991-1002.

Umuzdaş, S. ve Kızıklı, H.O. (2018). İlköğretim öğrencilerinin müzik dersine ilişkin tutumları. International Journal of Human Sciences. 15(3), 1561-1567. doi:10.14687/jhs.v15i3.5341 adresinden alınmıştır.

Umuzdaş, S. (2012). İlköğretim müzik dersine ilişkin tutum ölçeğinin geliştirilmesi. International Journal of Human Sciences [Online]. (9)2, 1510-1523.

Uyan, Z. D. (2012). Özengen müzik eğitimini alan ve almayan ilköğretim 6. sinıf ögrencilerinin akademik başarılarının ve okula yönelik tutumlarının incelenmesi. (Yayımlanmamış doktora tezi) Gazi Üniversitesi Eğitim Bilimleri Enstitüsü, Ankara.

Üstün, E. ve Özçimen, A. (2015). Okul çalgılarının ilköğretim 6. sınıf müzik dersi kazanımlarına ulaşmasındaki etkililiğinin incelenmesi. Akademik Sosyal Araştırmalar Dergisi. 3(10), 301-318. 
Üstün, E. (2014). Okul çalgılarının ilköğretim müzik dersi kazanımlarına ulaşmadaki etkililiğinin incelenmesi. (Yayımlanmış doktora tezi). Necmettin Erbakan Üniversitesi, Eğitim Bilimleri Enstitüsü, Konya.

Yılmaz, E. (2010). Okul şarkılarının klasik gitar ile eşliklendirilmesine yönelik öğretmen görüşleri ve okul şarkıları için eşliklendirme örnekleri. (Yayımlanmış yüksek lisans tezi). Niğde Üniversitesi, Sosyal Bilimler Enstitüsü, Niğde.

Yıldırım, C. (1999). Eğitimde ölçme ve değerlendirme. Ankara: ÖSYM

Varış, Y. A. ve Cesur, D. (2012). Ortaöğretim düzeyi müzik dersine yönelik tutum ölçeği geliştirilmesi. e-Journal of New World Sciences Academy. 7(4), 361-374.

\section{Summary}

\section{Statement of Problem}

Music teachers in primary schools should make use of audio and visual materials as much as possible based on the interests of the students and the characteristics of the subject. In terms of the developmental characteristics of the students, all kinds of materials used in music lessons especially at primary level become important in achieving the desired goals. The most functional and the most suitable material to reach the aim for a music instructor in the music classes of primary school is musical instrument. It is thought that the instruments used in music classes will enable students to learn easily and increase their interest and motivation. In addition, it can be ensured that the theoretical part of music course is reinforced with the instruments used in teaching.

Sources indicate that the child is able to recognize and distinguish sounds and rhythms through the use of instruments in the educational process. In this context, it is thought that the use of instruments and the choice of instruments to be used are important in achieving the goals of music classes and planning the activities.

The instruments to be used in music classes should be suitable for the students to accompany by vocal music and appropriate to the sound limits of the students, with certain rhythmic and melodic features. The instruments to be used in music lessons should be suitable for the students' sound limits and content-based acquisition. In institutions educating music instructors, the piano classes are given to the candidates, however, it can be very difficulty for many schools to get piano as accompaniment instrument due to their physical means of many schools. The instruments such as baglama, block flute and guitar are more likely to find than piano and are more preferable due to the place, space, cost and tuning issues. Piano is one of 
the most basic accompaniment instruments of music teachers. Trainings, available resources, methods, sound limits and suitability for students, as well as functionality have turned this instrument into a basic accompaniment instrument. The qanun as one of Turkish music instruments is accepted as one of the basic instruments with all these features of the piano. For this point of view, the study was carried out by baglama and qanun.

\section{Purpose of the Study}

In this study, it is aimed to determine the effect of music course practices with Turkish Classical and Folk Music instruments on course achievement and attitudes of primary school students. This study was conducted experimentally to determine the effect of this practice on groups. In this study, one randomly assigned control and two experimental groups were subjected to pre-test and post-test measurements; the effects of music classes with qanun and baglama on music course achievement and attitudes of primary school students were tested.

\section{Method}

The universe of the study consisted of 48 sixth grade students ( 24 girls, 24 boys) attending Ibni Sina Primary School in Tokat Turhal in the fall semester of 2018-2019 academic year. The study population was included in the sample.

The study was conducted in three different classes consisting of the same number of students. Two of the classes were experimental and one was the control group. In the fall semester, music classes were made by using the qanun in one of the two classes that were the experimental groups and the baglama to the other class. The control group was instructed to use the same content as the experimental groups without using instruments. 6th grade music course in the primary school was conducted with the subjects in the curriculum for 12 weeks.

30 -item “6th grade music course achievement test” for achievement test, and "Umuzdaş primary school music course attitude scale (2012)" in determining the attitudes of students were used. SPSS 22.0 (Statistical Program for Social Sciences) Shapiro-Wilks, Mann Whitney-U and Kruskall-Wallis Variance were used in the analysis of the data obtained.

\section{Findings and Discussion}

It is seen that there is no significant difference in the pre-test and post-test scores of the music courses with qanun. Based on these findings, it was understood that having the music course with "qanun" did not significantly affect the attitude and success of the students for the music course. When the average is examined, the attitude and achievement test scores of the experimental group students have made progress in the desired way after the practice, but this is not statistically significant. 
There is no statistically significant difference between the pre-test and post-test scores of the music classes performed with baglama. Based on these findings, it was understood that having the music course with "baglama" did not significantly affect the attitude and success of the students for the music course. When the means were examined, the attitude and achievement test scores of the experimental group students have made progress in the desired way after the practice but there is not statistically significant difference.

It is seen that there is no significant difference in pre-test and post-test scores in the music classes not using any instruments. Based on these findings, it was understood that having the music course without using the instrument did not significantly affect the attitude and success of the students for the music course. When the means were examined, although the attitude and achievement test scores of the control group students have made progress in the desired way after the practice, this is not statistically significant.

\section{Conclusions and Recommendations}

When the researches about the attitudes and achievements of primary school music students were examined; it is seen that the instruments used in music education have an important place in terms of music courses' performance. When the results obtained from the researches are examined, it shows that the music lessons used in the primary school music classes have a positive effect on the students' achievements and interests in the course. However, although the mean values of the instruments used in the experiment and the control group with no instrument training in this study and the mean values of the studied variables were different, they were not statistically significant.

Thus, the fact that there was no difference in the effect of the music course practices without using any instrument and the practices with the instruments on the attitude and success of the students in music course indicates a different result from the literature. The instruments chosen for the experiment did not affect the selected variables. This result, which is valid for this study and this sample, can be repeated and varied.

The studies conducted with different samples, questioning different variables and experimenting with different instruments are required to be diversified. It is advised for new researchers to contribute to the literature from this perspective. 